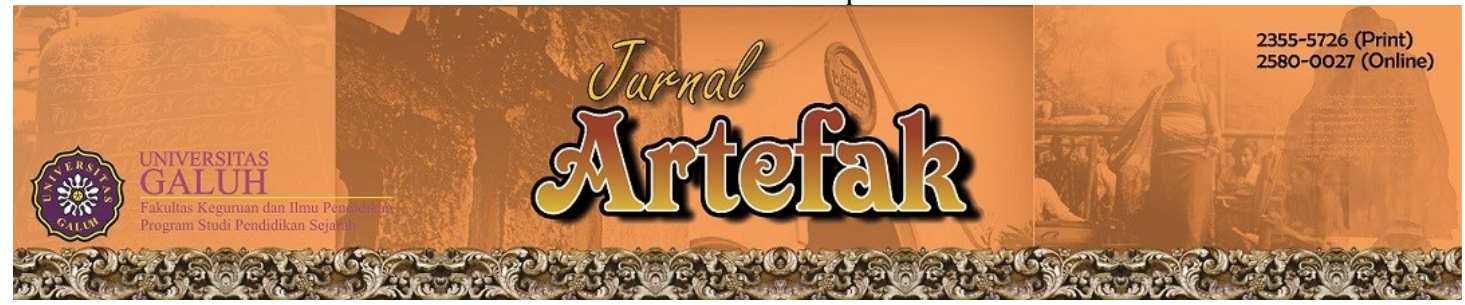

https://jurnal.unigal.ac.id/index.php/artefak/article/view/5454

\title{
ANALISIS PEMBELAJARAN IPS DARING PADA MASA PANDEMI COVID-19 DI SMP NEGERI 2 TARIK SIDOARJO
}

\author{
Izzatul Fajriyah ${ }^{1}$, Vici Biantami Putri Itaqullah ${ }^{2}$ \\ 1,2 Program Studi Pendidikan Sejarah, STKIP PGRI Sidoarjo, Indonesia \\ Email: izzafajriyah28@gmail.com ${ }^{1}$; viciputri35@gmail.com² \\ Sejarah Artikel: Diterima 7-7-2021 Disetujui 1-8-2021 Dipublikasikan 30-9-2021
}

\begin{abstract}
Abstrak
Penelitian ini bertujuan menganalisis bagaimana proses pembelajaran pada masa pandemi covid-19 yang dilakukan secara online (dalam jaringan). Penelitian ini juga menjelaskan faktor-faktor dalam proses pembelajaran IPS daring di SMP Negeri 2 Tarik Sidoarjo. Penelitian ini menggunakan metode kualitatif. Pada penelitian ini metode pengumpulan data yang digunakan adalah observasi dan wawancara. Subjek yang digunakan adalah guru IPS dan beberapa siswa SMP Negeri 2 Tarik Sidoarjo. Hasil penelitian menunjukkan bahwa pembelajaran IPS daring dilakukan dengan beberapa aplikasi. Aplikasi yang digunakan yaitu google classroom, google meet, dan whatsapp group. Dalam hal ini dibutuhkan kreativitas seorang guru untuk pencapaian tujuan pembelajaran. Kendala yang dialami siswa yaitu tentang pemahaman materi dan keterbatasan akses internet. Upaya pemecahannya adalah dilakukan kerjasama antara guru dan orang tua siswa dalam pembelajaran IPS daring di SMP Negeri 2 Tarik Sidoarjo.
\end{abstract}

Kata Kunci: Pembelajaran Daring, Mata Pelajaran IPS, Pandemi Covid-19

\begin{abstract}
This study aims to analyze how the learning process during the covid-19 pandemic was carried out online (in the network). This study also explains the factors in the online social studies learning process at SMP Negeri 2 Tarik Sidoarjo. This study uses a qualitative method. In this study, the data collection methods used were observation and interviews. The subjects used were social studies teachers and several students of SMP Negeri 2 Tarik Sidoarjo. The results showed that online social studies learning was carried out with several applications. The applications used are google classroom, google meet, and whatsapp group. In this case, teacher's creativity is needed to achieve learning objectives. Constraints experienced by students are about understanding the material and the limitations of internet access. The solution is to collaborate between teachers and parents in online social studies learning at SMP Negeri 2 Tarik Sidoarjo.
\end{abstract}

Keyword: Online learning, Social sciences learning, Covid-19 pandemic

\section{PENDAHULUAN}

Pandemi Covid-19 telah berdampak pada masalah pendidikan di Indonesia. Pembelajaran di sekolah harus dilaksanakan secara daring antara guru dengan siswanya (Asmuni, 2020). Tidak terkecuali, yang terjadi di Kabupaten Sidoarjo. Data yang dihimpun dari Satgas Percepatan Penanganan covid-19 di Jawa Timur. Merinci enam kabupaten dan kota yang statusnya zona merah yaitu, Sidoarjo, Probolinggo, Kota Pasuruan, Pasuruan, Banyuwangi dan Kota Malang (Purba, 2021). Oleh karena itu, rencana diberlakukan pembelajaran tatap muka di Kabupaten Sidoarjo ditunda. Pembelajaran di sekolah dilaksanakan secara online.

Pembelajaran merupakan suatu proses yang panjang agar mencapai hasil yang diinginkan. Untuk mencapai hasil tersebut maka diperlukan strategi yang tepat. Strategi pembelajaran adalah metode atau cara yang dilakukan oleh guru untuk menyampaikan materi pembelajaran kepada siswa dalam berlangsungnya perubahan aspek afektif, kognitif, dan psikomotorik secara berlanjut. Menurut Rohani, (2019: 5) media 
pembelajaran adalah wahana fisik atau komponen data yang berisi materi instruksional di lingkungan siswa dan dapat merangsang para siswanya untuk belajar.

Pembelajaran daring (dalam jaringan) telah diakui sebagai disiplin ilmiah dengan landasan teori, filosofi, praktik yang sudah mapan. Di Negara Indonesia, secara yuridisformal telah diakui sebagai subsistem pendidikan nasional, (Habe \& Ahiruddin, 2017). Pembelajaran saat ini bukan hanya dilakukan di dalam kelas, tetapi dapat dilakukan dimana saja. Pemanfaatan teknologi untuk sistem pembelajaran dapat menimbulkan pembelajaran menggunakan media elektronik. Pembelajaran jarak jauh berbasis pembelajaran daring ini merubah sistem pembelajaran pola tradisional atau konvensional menjadi pola bermedia. Diantaranya menggunakan media komputer dengan internet yang memaparkan apa itu $e$ learning.

Rencana mencegah penularan dan penyebaran Virus Corona di lingkungan sekolah. Kemendikbud memberikan kebijakan untuk menutup sekolah selama pandemi Covid-19. Pada masa penutupan sekolah, kegiatan belajar mengajar diubah menjadi Pembelajaran daring (Kemendikbud, 2020). Keputusan tersebut tentang Pedoman Penyelenggaraan Belajar dari Rumah di Masa Darurat Penyebaran Coronavirus Disease (Covid-19). Oleh sebab itu, sebagai seorang guru harus mempunyai beberapa inovasi pembelajaran yang kreatif. Agar pembelajaran yang dilakukan secara daring berjalan dengan lancar.

Pembelajaran Jarak Jauh telah dibagi menjadi dua jenis yaitu pembelajaran dalam jaringan (daring) dan pembelajaran luar jaringan (luring) sesuai edaran (Kemendikbud, 2020) (SE No. 15 Tahun, tentang Pedoman belajar dari rumah dalam masa darurat penyebaran Covid-19). Pembelajaran Luring adalah pembelajaran yang dilakukan oleh guru dan siswa tanpa menggunakan jaringan internet, HP. Tetapi, melalui buku pembelajaran pegangan guru dan siswa. Selain itu pembelajaran luring ini dapat mengakses dari radio dan televisi yang memberikan tayangan pembelajaran. Sedangkan pembelajaran daring (dalam jaringan) merupakan pembelajaran yang menggunakan jaringan internet dengan fleksibilitas, konektivitas, akses dan kemampuan untuk menerapkan berbagai jenis interaksi pembelajaran (Moore et al., 2011).

Media Pembelajaran daring dapat menggunakan layanan Edmodo, Schoology, dan Google Classroom (Enriquez, 2014). Media aplikasi pesan seperti WhatsApp serta dapat dilakukan melalui media sosial seperti Instagram dan Facebook (Purwanti, 2013). Pembelajaran daring dengan penggunaan teknologi mobile mempunyai sumbangan besar dalam lembaga pendidikan dalam mencapai tujuan pembelajaran Korucu \& Alkan, (2011: 192). Pembelajaran daring membantu guru yang tidak dapat mengajar langsung di dalam kelas. Dengan menggunakan pembelajaran daring, maka pembelajaran bisa dilaksanakan dimana saja, kapan saja tidak harus dilakukan dengan tatap muka.

Proses pembelajaran daring yang diterapkan selama masa pandemi Covid-19 tentunya akan mengalami kendala. Terutama, materi yang diberikan oleh guru terhadap siswanya. Hal ini berkaitan dengan tugas dan praktik yang diberikan guru. Kurangnya akses teknologi seperti lemahnya konektivitas internet yang baik. Terutama, siswa dari keluarga yang kurang mampu.

Pelaksanaan pembelajaran IPS daring di SMP Negeri 2 Tarik Sidoarjo. Guru IPS telah mengupayakan semua media yang telah difasilitasi oleh sekolah. Agar siswa tetap mendapatkan pelajaran yang sesuai dengan materi dan pencapaian tujuan pembelajaran IPS di SMP Negeri 2 Tarik Sidoarjo. Dari beberapa fakta yang telah terjadi selama masa pandemi Covid-19. Peneliti menemukan permasalahan yang telah dirasakan oleh guru yaitu proses pelaksanaan kelas daring mata pelajaran IPS pada siswa SMP Negeri 2 Tarik Sidoarjo. Permasalahan tersebut muncul dari guru maupun siswa. Seperti kurangnya kreativitas dalam memberikan materi oleh guru karena hanya mentransfer materi melalui Whatsapp Group. Kemandirian siswa saat belajar dari rumah secara daring (online) membuat siswa wajib memahami sendiri materi yang diberikan.

\section{METODE PENELITIAN}

Metode penelitian yang digunakan oleh peneliti adalah penelitian kualitatif. Tujuan penelitian kualitatif pada umumnya mencakup informasi tentang fenomena- 
fenomena utama yang dieksplorasi dalam penelitian, partisipan penelitian, dan lokasi penelitian (Nugrahani, 2014). Penelitian Kualitatif ditujukan untuk memahami fenomena-fenomena sosial dari perspektif penelitian atau sudut pandang. Partisipan adalah orang-orang yang diajak wawancara, diobservasi, diminta memberikan data, pendapat, pemikiran, implikasinya.

Penelitian dilaksanakan pada bulan Mei 2021. Pada bulan tersebut, SMP Negeri 2 Tarik Sidoarjo sudah menerapkan kebijakan pembelajaran daring. Subjek penelitian adalah Guru IPS dan beberapa siswa SMP Negeri 2 Tarik Sidoarjo. Prosedur penelitian ini diawali dengan menentukan masalah yang dibahas yaitu Penerapan Pembelajaran daring pada mata pelajaran IPS. Kemudian, kendala-kendala yang dirasakan oleh Guru IPS dan Siswa. Data dikumpulkan melalui wawancara dan observasi. Hasil penelitian diolah untuk menemukan tujuan penelitian.

\section{HASIL PENELITIAN DAN PEMBAHASAN}

\section{Proses Pembelajaran IPS Daring}

Proses pembelajaran IPS daring, berdasarkan wawancara dengan guru IPS Bu Sudilah, S.Pd. Proses pembelajaran di SMP Negeri 2 Tarik dimulai pada pukul 07.30 pagi hingga pukul 10.40 WIB. Pada satu jam pelajaran ada 20 menit. $\mathrm{Bu}$ Sudilah memberikan materi yang sudah disiapkan. Kemudian, dikirimkan ke google classroom kelas yang memiliki jam pelajaran IPS. Materi tersebut berupa link video pembahasan, materi sesuai dengan tema RPP yang digunakan. Selain, materi yang dikirimkan ke dalam google classroom ada juga tugas siswa. Menurut Arizona et al., (2020: 64) pembelajaran daring yang diterapkan dengan menggunakan media google classroom memungkinkan guru dan siswa dapat melangsungkan pembelajaran tanpa melalui tatap muka di kelas dengan pemberian materi. Untuk memberitahukan ke siswa kelas yang sudah siap menerima mata pelajaran IPS. Guru IPS memberitahukan melalui Whatsapp group agar jam sesuai dengan jadwal pelajaran.

Whatsapp group digunakan karena mudah dan dapat mengirim berupa link tugasnya. Siswa yang menerima pelajaran dari guru IPS langsung membuka google classroom untuk dapat menerima materi. Selanjutnya tugas yang diberikan dapat dikirimkan dalam bentuk video, Lembar Kerja Siswa (LKS). Cara siswa menyelesaikan tugas adalah mengerjakan tugas secara manual dengan cara menulis di buku kemudian foto hasil tugas dikirim melalui chat whatsapp dan dikirim ke guru IPS. Dalam upaya memantapkan penilaian, guru IPS juga menambahkan tugas dalam bentuk google form.

Pemanfaatan Whatsapp digunakan guru sebagai sarana untuk mengumpulkan tugas. Alasan guru memilih menggunakan whatsapp adalah lebih praktis, lebih mudah dipahami siswa dan lebih hemat. Media whatsapp tidak membutuhkan banyak kuota dalam proses pembelajaran. Alasan lain adalah semua orang tua siswa dapat menggunakannya dan bukan hal yang asing. Saat ini, whatsapp dapat dijangkau banyak kalangan. Jika ingin melakukan pertemuan secara virtual, guru dapat langsung menggunakan fitur whatsapp video call. Whatsapp bersifat sederhana, mudah dan juga efisien dalam penggunaannya.

Guru IPS juga memanfaatkan google meet untuk memberikan materi. Namun tidak setiap minggu, google meet dipergunakan awal pertemuan dan akhir pertemuan. Hal tersebut, agar guru dapat mengenal siswanya dengan melihat dan bertemu secara virtual. Siswa juga dapat mengetahui guru mata pelajaran dan mengenal guru IPS secara virtual. Media pembelajaran secara daring ini dapat digunakan untuk memperkenalkan pendidikan formal. Selain itu, menjadi penghubung antara siswa dengan guru ditempat yang berbeda. Hal ini diperlukan penggunaan sistem telekomunikasi dan akses ke berbagai sumber daya (Sobron et al., 2019).

Perencanaan merupakan tahapan yang penting untuk dilaksanakan di satuan pendidikan. Tanpa adanya perencanaan, sekolah dapat mengalami kesulitan untuk mewujudkan tujuan yang ingin dicapai. Perencanaan guru membuat Rencana Pelaksanaan Pembelajaran (RPP). Dalam pelaksanaanya guru menggunakan metode pembelajaran daring. Untuk evaluasinya guru memberikan tugas beserta soal-soal latihan. Kemudian guru mencatat mengoreksi jawaban siswa. Jawaban yang sudah dinilai 
oleh guru akan merekap pada catatan yang disiapkan sebelumnya.

Pembelajaran terstruktur merupakan seperangkat tindakan yang dirancang untuk proses belajar peserta didik dengan mempertimbangkan kejadian-kejadian internal yang berlangsung kepada siswa. Proses pembelajaran yang berhasil dengan memerlukan metode, teknik, serta pendekatan tertentu sesuai pada karakteristik tujuan siswa, sumber ajar, dan materi sehingga memerlukan strategi yang tepat (Lasapa \& Dkk, 2017). Pembelajaran terstruktur adalah bentuk pembelajaran sistematis, untuk pelaksanaan pembelajaran terstruktur, guru menyampaikan tujuan yang ingin dicapai dalam proses tersebut.

Berikut merupakan gambar aplikasi yang dipergunakan oleh guru IPS :

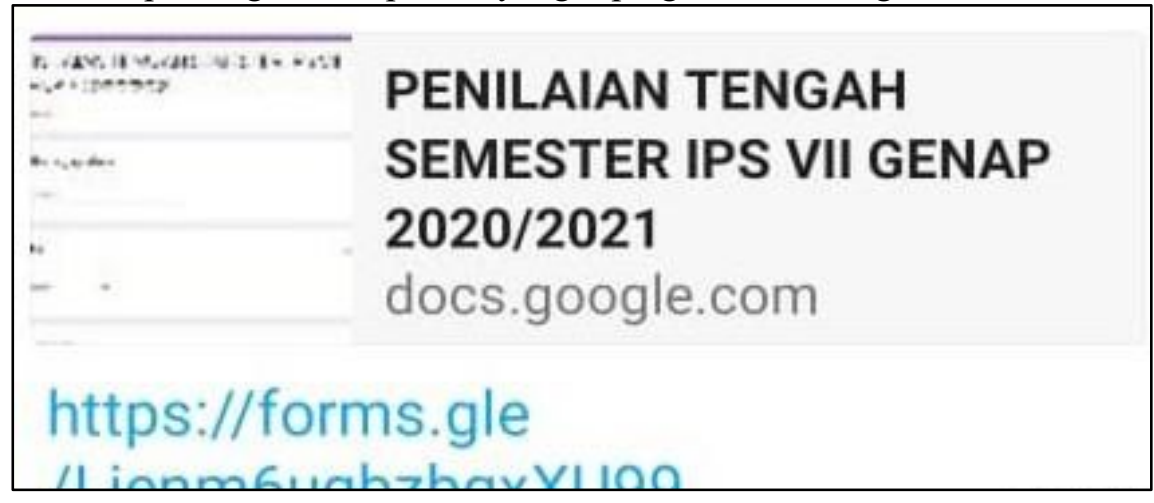

Gambar 1. Google form yang digunakan untuk Penilaian Siswa

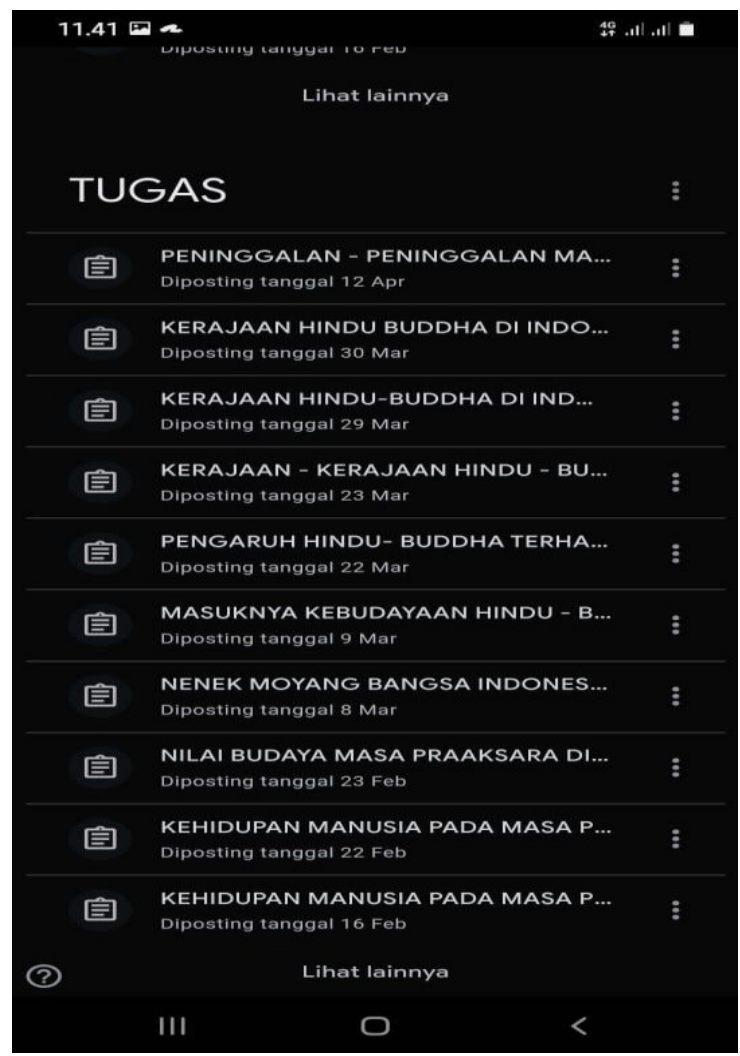

Gambar 2. Google Classroom berupa judul materi-materi mata pelajaran IPS 


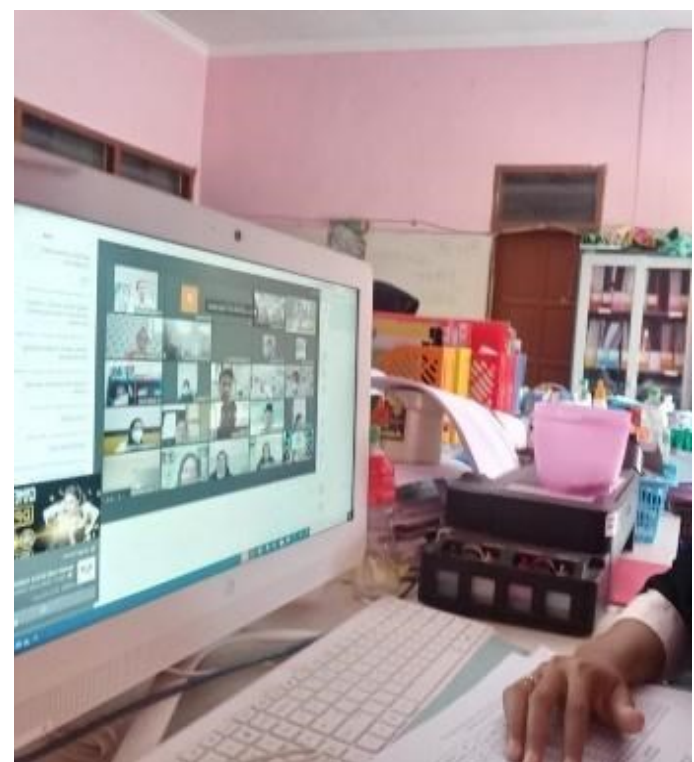

Gambar 3. Guru IPS SMPN 2 Tarik melakukan Pembelajaran Daring dengan menggunakan Google Meet

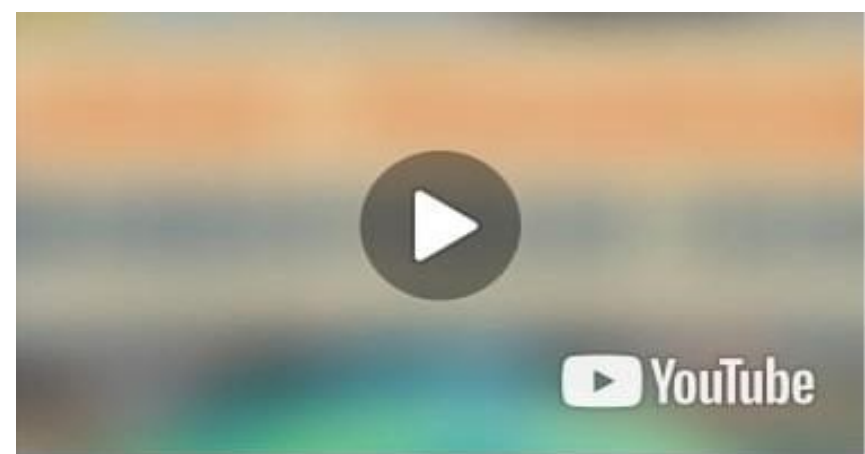

Belajar Sejarah - Sejarah

Pembentukan Bumi Zaman Praaksara \#BelajarDiRumah. www.youtube.com

\section{https://youtu.be/Fhb50wAdWJk}

Gambar 4. Materi berupa Video untuk diberikan kepada siswa

Partisipasi siswa SMP Negeri 2 Tarik Sidoarjo termasuk sedikit mencapai target. Tidak semua siswa memiliki ponsel sendiri untuk mengikuti pembelajaran daring oleh guru IPS. Beberapa siswa juga yang memakai ponsel milik orang tuanya ataupun keluarganya. Pada penelitian yang dilakukan oleh Budiyono, (2018: 60) kemampuan belajar siswa dapat dikelompokkan pada siswa berkemampuan rendah, sedang, dan tinggi. Siswa yang berkemampuan tinggi biasanya ditunjukkan oleh motivasi yang tinggi dalam belajar, kesiapan, dan keseriusan dalam mengikuti pelajaran dan lain sebagainya.

Pada dasarnya masalah belajar dapat digolongkan atas beberapa faktor. Faktor pertama dari siswa sendiri, seperti minat dan aktivitas belajar. Faktor selanjutnya adalah faktor keluarga dan lingkungan. Hal ini berhubungan dengan kemampuan ekonomi orang tua yang kurang memadai, dan anak yang ku.rang mendapatkan perhatian dan pengawasan orang tua (Susiani, Pargito, 2016). 
Kunci sukses untuk keberhasilan pembelajaran daring tersebut adalah komunikasi guru dengan orang tua siswa. Karena dalam proses pembelajaran ini siswa tidak dapat bertemu langsung dengan guru. Oleh karena itu, orang tua dapat menjadi guru utama di rumah. Adanya beberapa macam pekerjaan orang tua siswa yang membuat pembelajaran daring ini sendiri menjadi kurang maksimal. Orang tua siswa tidak bisa mendampingi anaknya untuk mengikuti pembelajaran daring. Dampak tersebut terjadi, pada minimnya akses dan efisiensi waktu ketika pembelajaran daring berlangsung.

\section{Faktor Pendukung Pembelajaran IPS Daring}

Faktor pendukung pada proses pembelajaran daring ini adalah Fasilitasi Wifi dari sekolah. Akses internet tersebut dipergunakan untuk mendukung para guru. Dalam menyiapkan dan memberikan materi pembelajaran daring kepada siswa. Fasilitas Wifi dapat digunakan guru IPS untuk membuat video pembelajaran sebagai materi dan mengirim video pembelajaran IPS tersebut kepada siswa.

Media yang digunakan untuk mendukung pembelajaran daring adalah ponsel yang dimiliki siswa maupun guru karena bersifat mudah dibawa kemana saja. Pembelajaran daring merupakan tantangan tersendiri bagi siswa. Sesuai dengan pendapat Jayul \& Irwanto, (2020:190) bahwa proses pembelajaran merupakan proses komunikasi. Proses penyampaian pesan dari sumber pesan melalui saluran / media tertentu ke penerima pesan pembelajaran daring. Pada dasarnya proses pembelajaran merupakan suatu kombinasi yang tersusun meliputi unsurunsur manusiawi, material, fasilitas, perlengkapan dan prosedur yang saling mempengaruhi mencapai tujuan pembelajaran.

Faktor pendukung yang lain yaitu, sekolah telah mengirim kuota internet gratis. Kuota tersebut terjadwal setiap bulan kepada siswa dari kelas VII sampai kelas IX. Seperti yang dijelaskan oleh guru IPS kelas VII ketika sesi wawancara berikut:

"SMP Negeri 2 Tarik telah memberikan guru akses WIFI gratis dan kuota internet gratis kepada siswa. Diharapkan mendukung pembelajaran daring yang sudah diberlakukan. Pemberian kuota internet gratis kepada siswa dan siswi mulai bulan agustus 2020. Para guru diwajibkan mendata nomor para siswa dan didaftarkan sesuai provider yang digunakan. Maka akan mendapatkan kuota internet gratis setiap bulan, sesuai anjuran oleh Pak Nadiem Makarim Kemendikbud".

\section{Faktor Penghambat Pembelajaran IPS Daring}

Pembelajaran daring bagi guru IPS juga mengalami kendala-kendala dalam penerapannya. Contohnya, guru IPS diharuskan untuk selalu siap mendampingi siswa dari pagi sampai malam. Guru memantau tugas melalui aplikasi whatsapp group. Hal ini berkaitan dengan kinerja guru IPS. Idealnya guru mempersiapkan materi untuk hari berikutnya. Namun, guru IPS masih merasa terbebani oleh materi yang belum tuntas di hari tersebut. Siswa yang belum mempunyai ponsel sendiri pun mengalami kesulitan untuk mengerjakan tugas yang diberikan oleh guru setelah mendapatkan materi

Faktor penghambat pembelajaran IPS daring selanjutnya yaitu antusias pada siswa yang kurang untuk mengikuti proses pembelajaran. Jumlah siswa tersebut, lebih dari setengah jumlah siswa di kelas. Seperti yang dijelaskan oleh guru IPS sebagai berikut:

"Antusias siswa pada saat mengikuti pembelajaran daring hanya sekitar $45 \%$ dari jumlah kelas".

Antusias siswa yang kurang juga mempengaruhi siswa untuk dapat memahami materi pembelajaran IPS. Pembelajaran IPS yang diberikan oleh guru dalam pembelajaran daring ini menjadi kurang efisien. Dengan munculnya pengalihan model pembelajaran yang baru. Tidak dapat dipungkiri munculnya kendala atau hambatan saat pembelajaran daring. Kendala tersebut berupa tugas yang menumpuk dan kurang memahami materi dan kurangnya motivasi belajar (Amalia, dkk, 2020).

Guru IPS menjelaskan bahwa minimnya persentase antusias siswa pada pembelajaran IPS daring mempengaruhi pemahaman siswa dalam materi yang telah diberikan.

"Dari seluruh siswa dalam kelas yang dapat memahami materi yang saya 
berikan hanya sekitar $40 \%$ hingga 50\% saja".

Faktor penghambat selanjutnya adalah terkendala dalam kuota internet dan jaringan internet yang tidak stabil. Jaringan yang tidak stabil dan kuota internet yang terbatas. Hal ini membuat siswa dan guru dalam proses pembelajaran daring mengalami kesulitan untuk memberikan materi. Seperti yang dijelaskan oleh Guru IPS kelas VIII ketika sesi wawancara berikut:

"Saat pembelajaran daring berlangsung dan ketika mengaplikasikan Google meet dan Google form seharusnya memiliki kualitas jaringan yang kuat serta kuota internet yang cukup untuk pembelajaran. Pada saat menggunakan aplikasi Google Meet dan Google Form itu menghabiskan banyak kuota siswa maupun guru".

Faktor terakhir yaitu kurang terstrukturnya pembelajaran daring. Materi video yang diberikan oleh guru kurang menarik siswa. Pada pembelajaran daring, guru dituntut untuk kreatif dan inovatif dalam membuat video pembelajaran. Seperti yang dipaparkan oleh siswa kelas IX SMP Negeri 2 Tarik Sidoarjo sebagai berikut :

"Saya sulit memahami materi yang diberikan oleh bu guru, kadang juga harus mencari sumber lain untuk mengerjakan tugas dari guru".

Selain, siswa yang bernama Zaky ada pula beberapa siswa yang mengalami kendala jaringan internet kurang lancar ketika harus menghadapi pembelajaran daring ini. Seperti salah satu siswa kelas VIII SMP Negeri 2 Tarik Sidoarjo sebagai berikut :

"Sinyal (jaringan internet) HP saya mbak lemot jadi kurang lancar saat membuka video dan mengumpulkan tugas, apalagi kalau video call (Google Meet). Kurang paham gurunya menjelaskan apa".

Hal ini menunjukkan bahwa ada beberapa siswa mengalami kendala berupa layanan jaringan internet dan kuota yang kurang memadai. Sesuai dengan penelitian Sadikin \& Hamidah, (2020:215) bahwa tantangan dalam pembelajaran daring atau secara online ini diantaranya yaitu ketersediaan layanan internet dan kuota yang kurang memadai. Dikarenakan pembelian kuota data internet mengeluarkan biaya yang cukup mahal.

Sebagaimana yang dijelaskan oleh Napitupulu, (2020: 24) ketidakpuasan terbesar dengan pembelajaran daring adalah karena ketidak stabilan jaringan. Siswa mengalami kesulitan jaringan internet yang mengganggu pembelajaran mereka. Jaringan merupakan faktor penting bagi lingkungan pembelajaran daring. Siswa menyoroti peningkatan jaringan, yang melayani ruang kelas pembelajaran daring, sebagai pertimbangan penting. Dalam pembelajaran daring ini, jaringan tidak hanya merupakan metode untuk mendistribusikan materi pendidikan. Namun, jaringan merupakan sarana untuk mempromosikan interaksi antara guru dan siswa.

\section{KESIMPULAN}

Penerapan pembelajaran IPS daring di SMP Negeri 2 Tarik Sidoarjo menggunakan aplikasi google meet, google form dan whatsapp group. Adapun faktor pendukung pembelajaran daring di SMP Negeri 2 Tarik Sidoarjo adalah fasilitas wifi dari sekolah, kuota bantuan dari sekolah untuk guru dan siswa. Siswa dapat menggunakan kuota tersebut untuk keperluan sekolah. Sedangkan, faktor penghambat pembelajaran IPS antara lain, guru tidak dapat menjelaskan secara maksimal, motivasi dan minat siswa dalam pembelajaran menurun. Kemudian, siswa kurang memahami materi yang telah disampaikan. Hal ini membutuhkan komunikasi yang baik antara guru dan orang tua siswa. Faktor penghambat terakhir tentang jaringan internet dari masing-masing siswa.

\section{DAFTAR PUSTAKA}

Arizona, K., Abidin, Z., \& Rumansyah, R. (2020). Pembelajaran Online Berbasis Proyek Salah Satu Solusi Kegiatan Belajar Mengajar Di Tengah Pandemi Covid-19. Jurnal Ilmiah Profesi Pendidikan, 5(1), 64-70. https://doi.org/10.29303/jipp.v5i1.111

Asmuni. (2020). Jurnal Paedagogy: Jurnal Paedagogy: Jurnal Paedagogy: Jurnal Penelitian Dan Pengembangan 
Pendidikan, 7(4), 281-288.

Budiyono, F. (2018). Analisis kesulitan siswa dalam belajar pemecahan masalah pada mata pelajaran IPS di SDN gapura timur I sumenep. Premiere Educandum: Jurnal Pendidikan Dasar Dan Pembelajaran, $8(1), \quad 60$. https://doi.org/10.25273/pe.v8i1.2516

Nugrahani, F. (2014). dalam Penelitian Pendidikan Bahasa. 信阳师范学院, 1(1), $305 . \quad \mathrm{http}: / \mathrm{e}-$ journal.usd.ac.id/index.php/LLT\%0Ahtt p://jurnal.untan.ac.id/index.php/jpdpb/a rticle/viewFile/11345/10753\%0Ahttp:// dx.doi.org/10.1016/j.sbspro.2015.04.75 8\%0Awww.iosrjournals.org

Enriquez, M. A. S. (2014). Students ' Perceptions on the Effectiveness of the Use of Edmodo as a Supplementary Tool for Learning. DLSU Research Congress, 6-11. https://doi.org/10.1017/CBO978110741 5324.004

Habe, H., \& Ahiruddin, A. (2017). Sistem Pendidikan Nasional. Ekombis Sains: Jurnal Ekonomi, Keuangan Dan Bisnis, 2(1), 39-45. https://doi.org/10.24967/ekombis.v2i1.4 8

Purwanti, H. (2013). Lembaran Ilmu Kependidikan. 42(2), 107-115.

Jayul, A., \& Irwanto, E. (2020). Model Pembelajaran Daring Sebagai Alternatif Proses Kegiatan Belajar Pendidikan Jasmani di Tengah Pandemi Covid-19. Jurnal Pendidikan Kesehatan Rekreasi, 6(2), 190-199.

Kemendikbud. (2020). Pedoman Penyelenggaraan Belajar Dari Rumah Dalam Masa Darurat Penyebaran Corona Virus Disease (Covid-19). Surat Edaran Nomor 15 Tahun 2O2O, 021, 120.

Korucu, A. T., \& Alkan, A. (2011). Differences between m-learning (mobile learning) and e-learning, basic terminology and usage of m-learning in education. Procedia - Social and Behavioral Sciences, 15, 1925-1930. https://doi.org/10.1016/j.sbspro.2011.04 .029

Lasapa, N., \& Dkk. (2017). Upaya Pembelajaran Terstruktur Dengan Pemberian Tugas Dalam Meningkatkan Prestasi Belajar IPS Pada Siswa Kelas
IV SD Inpres 02 Pongian Kecamatan Bunta. Jurnal Kreatif Tadulako Online, 5(1), 74-90.

Moore, J. L., Dickson-Deane, C., \& Galyen, K. (2011). E-Learning, online learning, and distance learning environments: Are they the same? Internet and Higher Education, 14(2), 129-135. https://doi.org/10.1016/j.iheduc.2010.1 0.001

Napitupulu, R. M. (2020). Dampak pandemi Covid-19 terhadap kepuasan pembelajaran jarak jauh. Jurnal Inovasi Teknologi Pendidikan, 7(1), 23-33. https://doi.org/10.21831/jitp.v7i1.32771

Purba, I. P. M. H. (2021). Implementasi Undang-UndangNomor 6 Tahun 2018 Tentang Kekarantinaan Kesehatan di Jawa Timur Menghadapi Pandemi COVID-19. Journal of Chemical Information and Modeling, 4, 1-11.

Amalia, R.U., Isnaeni, B., Purwanti,. Hanafi, Y. (2020). Analisis Kendala Peserta Didik dalam Pembelajaran Online Materi Biologi di SMP Negeri 3 Bantul.pdf. Jurnal Bio Education, 5, 10 15.

Rohani. (2019). Diktat Media Pembelajaran. Fakultas Ilmu Tarbiyah Dan Keguruan Universitas Islam Negeri Sumatera Utara, 1-95.

Sadikin, A., \& Hamidah, A. (2020). Pembelajaran Daring di Tengah Wabah Covid-19. Biodik, 6(2), 109-119. https://doi.org/10.22437/bio.v6i2.9759

Sobron, A. ., Bayu, Rani, \& Meidawati, S. (2019). Pengaruh Daring Learning terhadap Hasil Belajar IPA Siswa Sekolah Dasar Abstrak. Seminar Nasional Sains \& Entrepreneurship, 1(1), 1-5.

Susiani, Pargito, M. T. B. S. J. (2016). Peningkatan Minat Dan Aktivitas Belajar IPS Menggunakan Media Wayang Kardus Pada Siswa 1, Jurnal Studi Sosial Vol 4, No 1 (2016). Jurnal Studi Sosial, 4(1), 53-60. 